Article

\title{
The Crash of a Policy Pilot to Legally Define Community Energy. Evidence from the German Auction Scheme
}

\author{
Kerstin Tews ${ }^{1,2}$ \\ 1 Environmental Policy Research Centre, Freie Universität Berlin, 14195 Berlin, Germany; \\ kerstin.tews@fu-berlin.de; Tel.: +49-30-838-55098 \\ 2 Bavarian School of Public Policy, Technical University Munich, 80333 Munich, Germany; \\ kerstin.tews@hfp.tum.de
}

Received: 29 August 2018; Accepted: 21 September 2018; Published: 24 September 2018

\begin{abstract}
Community energy" is a highly contested issue not only in the German energy transition governance but also in the recent legislative procedure to recast energy market legislation within the EU's "Winter Package". This paper analyses the effects of the privileges for "community energy actors" in the German auction scheme for on-shore wind energy. Those privileges aim to guarantee a level playing field for small actors and to enhance societal acceptance. The results of the first rounds of auctions did not merely reveal an acceptable level of losses due to recognized trade-offs between policy objectives. Instead, the results indicate a complete failure regarding all three objectives of the revised support scheme for renewables-controlled renewable energy expansion, actor plurality and cost efficiency. The paper discusses whether the policy motivations translate appropriately into legislation. It suggests differentiating clearly the economic risks for small actors from the added value that is attributed to community energy actors. De-coupling these-often mixed-motives behind the demands for actor plurality unveils policy approaches that more adequately fit with these distinct motives. The paper finally proposes rather to integrate the politically desired values into the bid evaluation criteria instead of granting privileges to specific actors that are assumed to provide these values.
\end{abstract}

Keywords: renewable energy; governance; community energy; citizens' energy companies; actor plurality; acceptance; energy transition; auction scheme; Germany

\section{Introduction}

"Community energy" is a highly contested issue not only in the German energy transition governance but also in the recent legislative procedure to recast energy market legislation within the EU's "Winter Package" [1].

In Germany, "community energy actors" significantly pushed the deployment of renewable energies (RE) in the past. In the course of the shift of the support scheme for renewable energies from a price-based feed-in tariff to a volume-based competitive auction, the German Government for the first time legally defined the term "citizens' energy companies". This term was officially established in order to select those energy actors who were privileged by special auction rules. These special rules were justified by the policy objectives to enhance actor plurality and societal acceptance of the energy transition.

The paper analyses effects of the German provisions to privilege "community energy actors" against the background of the objectives of the revised German renewable energy policy. It finds that the results of these provisions for community energy actors in the German auction scheme do 
not just represent an acceptable level of losses due to recognized trade-offs between the three main objectives-controlled RE expansion, actor plurality and cost efficiency—but instead a complete failure with regard to all three of these objectives.

The paper takes a closer look at the motivations that officially underpinned these special provisions for citizens' energy actors in order to draw lessons from that policy pilot. These lessons might also help other European countries implementing the envisaged EU energy market legislation in the future. The EU-Parliament's version of the recast renewable energy directive suggests that member states have "[ ... ] to put in place an enabling framework to promote and facilitate participation by renewable energy communities in the generation, consumption, storage and sale of renewable energy" [2] (article 22(2a)).

The paper suggests to clearly distinguish between the risks for small actors to take part in auctions from the added societal value, attributed to the energy related activities of these actors. This approach will help to define the necessary policy design elements that are suitable to enable small and community energy actors to participate in energy market activities, to provide the politically desired benefits, and to prevent disastrous policy failures similar to those in the German case.

\section{2. "Community Energy" in the German Energy Policy Context}

\subsection{Occasion: Instrumental Shift in the Support Scheme for Renewables}

The term "community energy" or "citizens' energy" entered the political agenda in the course of the debate on the shift of the national support scheme for renewable energy. In 2014, the German government decided to switch from a price-based to a volume-based support scheme. This fundamental instrumental shift was "forced" by external pressure (EU-Commission's State Aid Guidelines [3]) on the one side, but also by domestic debates about the affordability of the energy transition and the increasing costs of RE deployment on the other side (for more details on drivers and implications of this instrumental shift, see [4]).

The price-based support scheme for RE-the so-called feed-in-tariff-functioned as a shelter, allowing small-scale renewable electricity producers to develop in a niche. These new actors have challenged established patterns of domestic energy policy interaction through experimentation and innovation at a decentralized level [5]. According to a survey carried out by trend:research $\mathrm{GmbH}$ and the Leuphana Universität Lüneburg [6] nearly half (46.6 percent) of the total RE capacity installed in Germany was owned by citizens and collective citizens' energy initiatives before the introduction of the auction scheme. It has been argued by many scientists and proponents of this "bottom-up" energy transition that these new energy actors are not purely driven by maximum profit-seeking motives (e.g., [7]). Instead, they combine their engagement in energy business with a common good orientation in terms of local development, inclusive democracy, citizens' engagement and social innovation.

\subsection{Risk of Auction Schemes and Measures of the German Government to Counter These Risks}

Many stakeholders perceived the instrumental shift as a serious threat for a further engagement of these new energy actors who have driven the transition in Germany thus far. Various empirical studies pointed to the risks of auction schemes (i.e., [8,9]). Auctions would disadvantage local small-scale investors, as they are less able to diversify risks related to the uncertainty of successful bids and to cover higher transaction costs associated with the participation in auctions. In addition to the loss of actor plurality, these studies have pointed to various other risks. They comprise the threat of spatial concentration of generation facilities (hotspots) and the respective high burdens on the grid infra-structure, innovation barriers due to the exclusion of less mature RE technologies as well as the risks of low actual project implementation rates, as demonstrated by the experiences of auction schemes in other countries. Low implementation rates would in fact threaten the main purpose of a volume-based and competitive coordination mode for RE development: the cost-effective achievement of the politically determined annual RE expansion targets. 
These other risks were discussed during consultations and the German government introduced various legal provisions into the Renewable Energy Act (EEG) to counter these risks:

(a) The "reference yield model", for example, was adapted in order to prevent hotspots in particularly wind-intensive geographical areas. It aims to enable wind energy plants to operate throughout the federal territory by remunerating at different rates, depending on location. However, the actual bid in a given tender has to refer to an administratively defined reference site in order to make the calculated prices of the competing bids comparable.

(b) The German government additionally opted for technology specific tenders to counter the risk of blocking further development of (less mature) RE technology and to safeguard diversification of the RE sources. The recent results of the first pilot auction round combining wind and PV verified the relevance of this approach. All awards in this combined pilot tender went to PV-based bids [10].

(c) The core approach to handle the risk of low implementation rates and, thus, to miss the expansion targets was the concept of "late" auctions. "Late" refers to the point in time of the development process of a given wind energy project. As a rule, the construction permit (grant of approval pursuant to the Federal Immission Control Act, BImSchG) is a central pre-qualification to participate in a tender. Granting this construction permit is a complex process, as all potential environmental impacts of the specific planned wind turbine/park have to be considered. This process requires time, knowledge and capacities, i.e., it induces a high amount of transaction costs. Having passed this process successfully can be assessed as an indicator for a high propensity of actual implementation of the awarded bids. The short implementation deadlines of maximum 2.5 years aim additionally at achieving expansion targets without delay.

Particularly, the knowledge about the political intention of conceptualizing "late" auctions, i.e., to guarantee high and timely implementation rates, also helps to understand the implicit assumptions underpinning the special regulation for citizens' energy companies. It will also help us to evaluate the impact of that special regulation according to the empirical results of the auction schemes in Germany as will be presented in the following sections.

\subsection{Legal Definition and Special Provisions for Citizens' Energy Companies}

During the debate on the revision of the EEG, the German government repeatedly declared that it will pursue actor plurality in its future energy transition efforts and will not threaten regional and local efforts towards a low-carbon energy transition. The results of the previous pilot bidding rounds on ground mounted photovoltaic systems (2014-2016) verified the concerns regarding a loss of actor plurality and the exclusion of small players. The majority of the capacity awarded went to bidders with more than one bid and bidders who feature intercompany ties with other successful bidders (see [5]). Confronted with these results the government introduced special regulations in order to create a level playing field for local citizen-based energy companies related to wind specific tenders.

\subsubsection{Definition of "Citizens' Energy"}

The revised EEG_-adopted in 2016 and entered into force in January 2017-for the first time legally defined the term "citizens' energy".

§ 3 EEG 2017 defines a citizens' energy company as an entity,

- " which consists of at least ten natural persons with voting right

- in which at least 51 percent of the voting rights are held by natural persons which live in the urban or rural district in which the onshore wind energy installation is to be erected,

- in which no member or shareholder of the undertaking holds more than 10 percent of the voting rights of the undertaking" [11]. 
§ 36g EEG 2017 furthermore defines, that

- members or shareholders are not allowed to have concluded contracts to transfer shares or voting rights in order to circumvent provision of $\S 3$;

- in the case of a successful bid, a 10 percent financial stake has to be offered to the municipality, where the installation is erected;

- The scale of the bid is restricted: up to six wind turbines or a maximum capacity of $18 \mathrm{MW}$ (ibid.).

However, community energy or citizens' energy is not a uniform phenomenon. Literature offers a variety of terms, characteristics, narratives which represent different theoretical approaches and ideational concepts (e.g., [12] (p. 897)). The German Government's approach to legally define those actors that are eligible to benefit from the special legal provisions tried to operationalize particularly the following characteristics:

(a) small scale nature and limited number of projects;

(b) citizens' control and

(c) locality of investments and returns.

The motivations underlying this set of criteria were to counteract small players' risk of having to bear up-front costs without guarantees to win auctions, and their limited opportunity to di-versify this risk through multiple projects. An additional and related motivation was to buttress acceptance of the local population via the local embeddedness of investors. Thus, the target of the special provisions was to create a level playing field for these actors in an imperfect market mainly for competition concerns.

Furthermore, successful bids by citizens' energy companies are awarded according to the uniform pricing principle in contrast to pay-as-bid principle for "ordinary" bidders. The uniform pricing principle means that the value of the award for bids of citizens energy companies shall be the value of the award of the highest bid awarded in the respective auction round.

\subsubsection{Special Auctioning Rules for Citizens' Energy Companies}

$\S 36 \mathrm{~g}$ of the EEG 2017 defines those special rules, which solely apply to citizens' energy companies (CEC). They are intended to provide the necessary level playing field for these actors to participate in auctions. The most relevant provisions comprise

(a) the allowance to submit a bid before the granting of the construction permit (pursuant to the Federal Immission Control Act (§36g(1)), and

(b) the allowance of longer realisation times for project implementation of up to 4.5 years compared to 2.5 years for "ordinary" bidders $(\S 36 \mathrm{~g}(2))$.

These exceptional provisions can be perceived as a fundamental derivation from the core principle of the German auction scheme-the principle of "late" tenders. Having in mind the underpinning motivation of "late" tenders-safeguarding target achievement—it becomes clear that the legislator implicitly assumed citizens' energy as a rather small segment among the potential bidders.

\section{Impact of Special Regulation for Citizens' Energy Companies}

\subsection{Success of Citizens' Energy?}

In contrast to any expectation and to many concerns of citizens' energy advocates about potential shortcomings of the EEG's provisions for citizens' energy, the results of the first auction in May 2017 surprised with an overwhelming success of bidders that made use of the special rules for citizens' energy companies. The privileges for CEC, conceptualized as exceptions, became the rule in the market "game".

Shocked by this unintended result which seriously threatened the achievement of the planned RE expansion and climate targets, the German Bundestag immediately announced a moratorium 
regarding $\S 36 \mathrm{~g}(1)$ and stopped the possibility for CEC to offer a bid before the construction permit has been granted. However, this moratorium took force only for the fourth and fifth auction rounds in 2018, before a final adaptation of the EEG will be implemented. Consequently, also in the second and third auction round in 2017, citizens' energy companies won almost all of the awards (see Figure 1).

How to interpret these results? Do they represent the legislator's failure to assess ex-ante the strength and volume of the citizens' energy segment? Or, did the legal definition not suffice to address the intended actors-citizens which initiate on their own wind energy projects in their neighborhood? Or, is the privilege offered to citizens' energy companies so economically attractive that even professional energy actors altered their projects into projects which fit with the legal definition of a CEC-project? Or is there something inconsistent within the whole policy design?

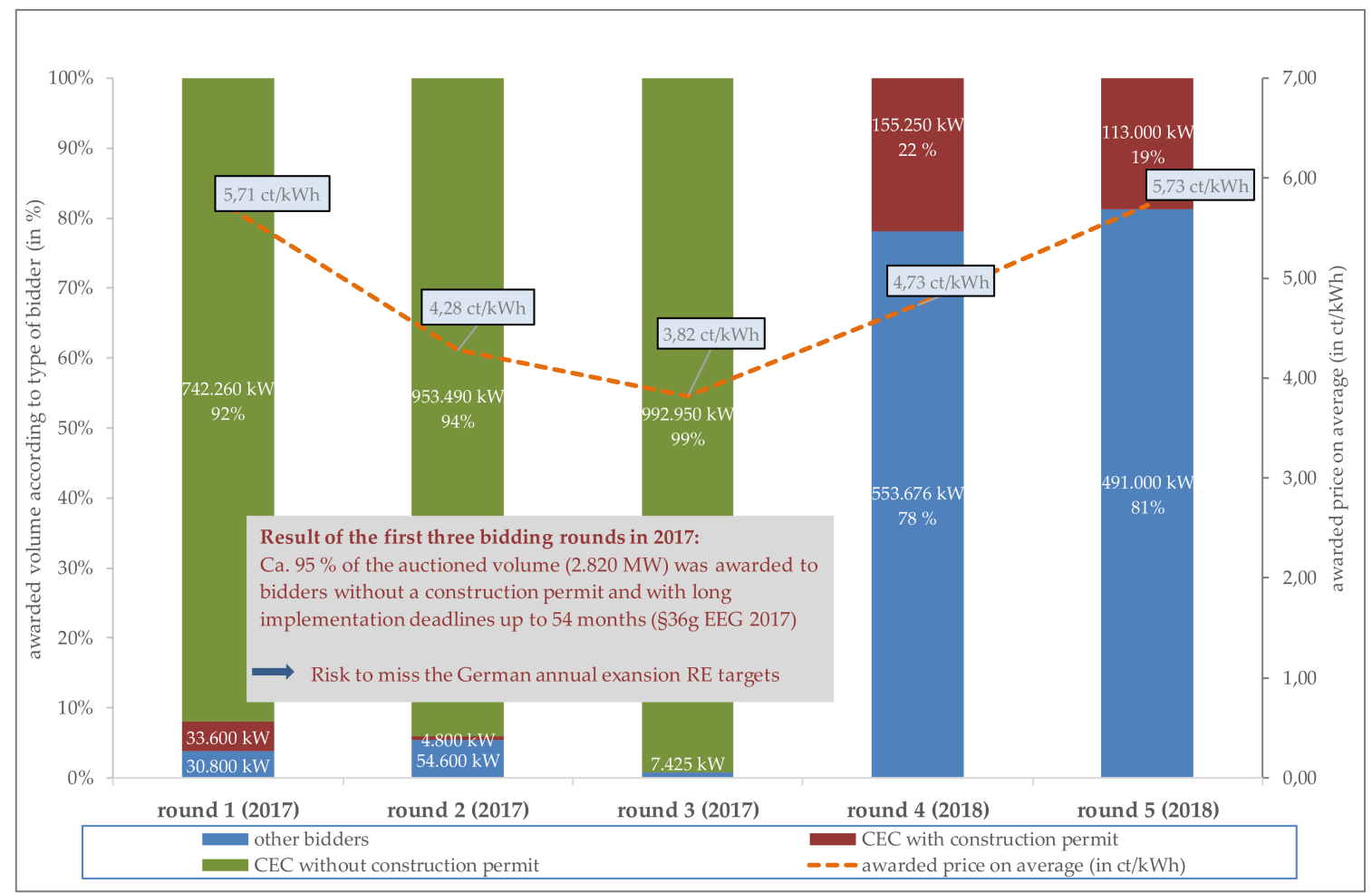

Figure 1. Results of the first 5 bidding rounds on onshore wind in 2017/2018; Source: Author's figure based on data from Bundesnetzagentur [13].

\subsection{CEC as Business Model for Rational Economic Actors}

The press release of the Federal Network Agency (Bundesnetzagentur) regarding the results of the first auction round in May 2017 [14] rather neutrally reported the success of citizens' energy. The press release following the second bidding round already revealed the Agency's awareness about the character of the successful CEC bidders: "The majority of the awards for bids of citizens' energy companies go to companies whose bids make it clear that they are at least organisationally assigned to a single project developer" (author's translation of the press release, [15]).

The single project developer mentioned in the press release-the Saxonian UKA-Group-is ac-cording to data from 2016 the second biggest developer of on-shore wind energy project in Germany. In an interview for the magazine "Erneuerbare Energien" in November 2017 the company's managing partner, Gernot Gauglitz, publicly explained the company's strategy as the most adaptive business model to comply with the induced competitive pressure in the German auction scheme [16] According to him, UKA was forced to emulate the behaviour of other project developers that won in the first bidding round, where UKA failed to win any of its "ordinary" bids. The adaptation of its strategy was 
so successful that UKA-connected CEC dominated the second bidding round with a 68 percent share of the total awarded volume (see Table 1).

Table 1. Results of the second bidding round in 2017: A single player's dominance.

\begin{tabular}{|c|c|c|c|}
\hline $\begin{array}{l}\text { Total Number of } \\
\text { Awards }\end{array}$ & Awards for CEC & $\begin{array}{l}\text { Awards for UKA-Connected } \\
\text { CEC-Bidders }\end{array}$ & $\begin{array}{l}\text { Share UKA of Total } \\
\text { Number of Awards }\end{array}$ \\
\hline 67 & 60 & 37 & $55 \%$ \\
\hline $\begin{array}{l}\text { Total awarded } \\
\text { volume }\end{array}$ & $\begin{array}{l}\text { Awarded volume } \\
\text { for CEC }\end{array}$ & $\begin{array}{l}\text { Awarded volume for } \\
\text { UKA-connected CEC-bidders }\end{array}$ & $\begin{array}{l}\text { Share UKA of total } \\
\text { awarded volume }\end{array}$ \\
\hline 1013 MW & $958 \mathrm{MW}$ & $690 \mathrm{MW}$ & $68 \%$ \\
\hline
\end{tabular}

In sum, the successful bidders privileged as CEC were set up by a very small number of professional project developers, who do not act as shareholders or members of the CEC-according to the legal definition-but as general contractors or service providers. A brief analysis of data of the Bundesnetzagentur [13] and the online-trade register [17] about the winners of the second round revealed that a lot of the successful CEC were formally founded just a few days before the auction deadline. They also have similar names, for example "Umweltgerechte Bürgerenergie", and—although the planned erection site is located in different municipalities-the registered office of those formally distinct CEC is the same and situated in the Saxonian town Meißen, identical with the postal address of UKA.

In fact, those project developers, who transformed their projects into CEC-projects made use of the privileges for CEC:

- $\quad$ to take part in the bidding procedure without having a construction permit, and

- $\quad$ the longer time span between awards and realisation deadline (up to 4.5 years).

These provisions offered opportunities for underbidding other "ordinary" bidders, a well-known phenomenon of competitive auction schemes. The exceptions-intended to support a small segment of rather unprofessional citizen-based projects-were used by typical business actors in an economically rational way. They calculated their expected returns (bids) with more effective wind turbines which according to their market analyses will only be developed in the near future. Thus, these special provisions for CEC have been used by professional actors to an extent that devaluated all existing construction permits for wind energy projects, as these permissions always have to relate to a specific type of an available wind turbine technology [18] (p. 4).

In sum, it can be stated that professional project developers, like UKA, have carefully analysed the market as well as the political framework conditions, and have rationally adapted their business model. Although diverse media—such as the German newspaper "Die Welt" — criticized "the dirty tricks with citizens' energy" [19] (author's translation), the CEC connected with these project developers meet all legal requirements of a CEC. Thus, the expressed complaint, it would be "fake" CEC that won the awards does suggest a knowledge, what "real" CEC is. Unfortunately, "real" CEC is not clearly defined-neither in scientific literature nor in the definition of citizens' energy in the EEG.

\subsection{Evaluation: Total Failure Regarding the Intended Triangle of Objectives}

As almost $95 \%$ of the auctioned volume in 2017 was awarded to bidders without a construction permit, it is doubtful how many of these projects will actually be realised. This results in uncertainty whether one core element of the instrumental shift-the volume-based approach to steer RE expansion - can be actually achieved. Additionally, the longer implementation deadlines of up to 54 months for these projects indicate that most of them-if ever-will not be realised before the year 2020. According to the Green Party in the German parliament, this would cause a sharp decline of the annual expansion of wind energy in Germany to 1500 MW or less in 2019 and 2020 compared 
with 5000 MW per year in 2016 and 2017. Moreover, this would imply missing the German and the mandatory European renewable energy targets [20].

The wind energy industry is complaining tremendously about these results as they represent a serious threat to their business model: uncertainties regarding the actual demand of wind turbines and/or the expected delay of the installation of wind turbines that is assumed to create a serious investment gap for the wind energy industry [18] (p. 4).

As explained above, the auctions were not able to foster actor plurality, the second core objective of the specific provisions, either. Instead, a small number of professional project developers dominated.

What about cost efficiency, the third objective of the German volume-based auction scheme and the core argument of proponents of competitive approaches to determine the price for RE?

At first glance, Figure 1 obviously illustrates a considerable decrease in the average price per $\mathrm{kWh}$ of wind energy in the first three bidding rounds, from $5.71 \mathrm{Ct} / \mathrm{kWh}$ to $3.82 \mathrm{Ct} / \mathrm{kWh}$. The remuneration that would have been paid according to the previous administratively fixed feed-in-tariff (EEG 2014) would be-nominally averaged $-6.16 \mathrm{Ct} / \mathrm{kWh}$ for plants erected at the beginning of 2018 [21]. Thus, it was claimed by the government that this core objective was reached by the German auction scheme.

However, the price results presented in Figure 1 are determined by the calculated prices of the bids. They do not show the actual remuneration according to the wind situation at the erection site as defined in the above-mentioned reference yield model. The awarded projects of the auctions in 2017 are planned to be erected at locations of a middle wind quality of $90 \%$ (first bidding round) or $85 \%$ (second and third bidding round) of the wind quality at the standard reference side [21]. That means that actual remuneration payments will be higher than prices calculated for the bids.

Researchers of the German Fraunhofer Institute IEE and IZES have questioned the alleged cost-cutting effect [21]. They simulated a comparison of remunerations based on the previous price-based support scheme and the results of the current volume-based support scheme by considering the reference yield model-i.e., the wind-quality at the erection site of the awarded CEC projects in the first three bidding rounds in 2017. They discovered up to one-fourth higher costs of the awards for CEC projects in the first bidding round compared to the previous remuneration based on the feed-in tariff scheme. Only the results of the third bidding round have shown a 10 percent reduction of the level of remuneration compared to the previous system [21]. Keeping in mind that these prices were a result of the very specific underbidding approach of successful bidders incentivized by the special provisions of $\S 36 \mathrm{~g}$, the magnitude of this decrease can be seriously questioned. The subsequent increase in the average prices per $\mathrm{kWh}$ after the moratorium took force in 2018 confirms this assessment (see Figure 1). Energy experts had expected this price increase [21]. All bidders with construction permits, including the unsuccessful bidders of the first three rounds, had to calculate their bids based on the available wind technology and no longer needed to adjust their bids to the expected underbidding strategy of privileged bidders without permits.

\section{Discussion}

What kind of lessons can we draw from this severe policy failure to meet the intended objectives?

The German legislator has integrated secondary policy objectives-a geographically more balanced distribution of wind energy plants and actor plurality-into an economic instrument, which mainly addresses the economic efficiency of the price building process. A trade-off with the economic efficiency objective of the auction scheme was-according to the legislator's justification of the German auction design [22] (p. 147)—politically accepted. Such trade-offs are quite common outcomes of political processes, whose protagonists have to find compromises between interdependent policy objectives.

\subsection{Inadequate Integration of Secondary Objectives}

However, the results of the German auction scheme do not represent a more or less acceptable level of assumed losses due to recognized trade-offs between the three main objectives of controlled 
RE expansion, actor plurality and cost efficiency. Instead, we see a complete failure with regard to all of these three objectives (see above).

There might be economists that feel confirmed in their assessment that any intervention into a market would be a market distortion and should therefore be avoided. However, the renewable energy market would not exist without state intervention and a piecemeal criticism of (presumed) market distortion would be the wrong lesson from the German "disastrous" policy pilot to create a level playing field for new citizens-based energy actors.

A closer look at the policy motivation underlying the definition of citizens' energy companies and the relation between these motivations and their operationalisation might give us more insights to draw adequate lessons.

Integrating the objective of "actor plurality" into the policy design of the German auctions scheme was motivated by, first, purely competition concerns to prevent market dominance of a few big energy actors [22]. This challenge was met by general provisions that may counteract the risks of small actors-e.g., a generalized de-minimis threshold of $750 \mathrm{~kW}$. However, the German legislator additionally defined an enabling policy framework for certain small actors to participate in wind energy auctions. The sole argument to explain that specific focus on citizen-based energy companies can be derived from the official justification of $\S 36 \mathrm{~g}$ EEG 2017: "In particular, locally anchored citizen energy companies have made a significant contribution to the necessary acceptance of new on-shore wind energy projects. Without this acceptance, the expansion of wind energy cannot be achieved in the planned amount" (author's translation, [22] (p. 217)).

However, if citizens' energy is perceived by the legislator as the provider of the necessary acceptance of wind energy expansion, then it seems to be inconsequential, that the citizens' energy segment was implicitly conceptualized as just a small segment among the potential bidders. To reiterate, all the special rules for CEC are a fundamental derivation from the core principle of the German "late" auction design (see above).

\subsection{The Need to Decouple Multiple Motives}

A possible approach to learn from these failures is to distinguish clearly between the two motivations underlying the objective "actor plurality". The first one addresses the risks of small actors, and the second one addresses the added value provided by citizen energy actors. De-coupling these two motivations might be helpful to find an adequate policy design.

\subsubsection{Addressing the Risks of Small Actors}

If design elements are supposed to help to safeguard market access for small actors for com-petition concerns, then the very specific risks of small actors must be addressed. This could be realized either with support measures outside of the auction, e.g., by providing counselling during preparation of a bid, or by exempting small actors from auctions altogether. Currently, the German generalized de-minimis threshold for exemptions from competitive tendering is at $750 \mathrm{~kW}$. However, this threshold has in fact no relevance for wind energy projects, as the market standard of available wind turbines is above this threshold at 2.5 to $3 \mathrm{MW}$ on average. The German Government rejected to use the full room for maneuver to exempt smaller projects from tendering which has been given by the European Commission state aid guidelines [3]. According to the EU Competition Commissioner's clarification from January 2016 about the misleading formulation of the de-minimis rule for wind power in the state aid guidelines, there is a possibility of "exemption from the competitive tendering requirement [...] for wind projects with a maximum of $18 \mathrm{MW}$ installed power" [23] (author's translation of the answer of Competition Commissioner Margrethe Vestager to the German Federal Wind Association). 


\subsubsection{Addressing the Added Value Attributed to Community Energy Actors}

However, if acceptance is the determining criterion, then we need to look in more detail at what in fact contributes to societal acceptance, as the legislator did not specify sufficiently, why citizen energy actors have significantly contributed to this objective. The items "majority of natural persons" of the members or shareholders of the CEC and their "place of residence" in the district of the planned wind energy plant have been used to operationalize characteristics of citizen-based energy actors and local embeddedness. Both characteristics are often linked in the literature with acceptance issues (e.g., [24]).

Yet, it is not too difficult to imagine that ten individual citizens who invest in a joint local economic undertaking can also act in a purely egoistic manner, i.e., without taking into account economic welfare or social acceptance in their neighborhood in a more caring manner than other economic actors. The acceptance issue, thus, was not operationalized, but only attributed a priori to community energy actors.

The acceptance issue is also a core objective of the EU's so-called Winter Package "Clean Energy for All Europeans" [1]. Currently the Recast Renewable Energy Directives and the Recast Electricity Market Directive are subject of the Trilogue between Commission, Council and Parliament. Both recast directives include definitions and special provisions for local (renewable) energy communities. Whereas the Commission and the Parliament strongly favor an enabling framework for community energy actors in their positions concerning theses directives, the Council's amendments to the Commission's proposals [25] indeed rather pronounce the costs induced by community energy actors and their financial responsibility "... for the imbalances they cause in the system" [26] (p. 62).

The European Commission (EC), assisted by the European Parliament, has "discovered" the added value that local community energy can provide. In its proposal for the Recast Electricity Directive the EC defines local energy communities (LEC) in the following way (article2(6)): "Local energy community means: an association, a cooperative, a partnership, a nonprofit organisation or other legal entity which is effectively controlled by local shareholders or members, generally value rather than profit-driven, involved in distributed generation and in performing activities of a distribution system operator, supplier or aggregator at local level, including across borders." [25] (p. 52, author's emphasis).

Thus, the Commission includes in its definition not only the various energy business activities a LEC can perform, but also declares "local control" and "value-driven" as key features making community energy actors distinct from other energy business actors. The added value for the European energy transformation process the EC attributes to LEC in its recitals for the recast electricity directive can be summarized as follows: LEC provide common goods: "Community energy [ . . ] help[s] fight energy poverty [ ... ] enables certain groups of household consumers to participate in the energy market $[\ldots]$ Where they have been successfully operated such initiatives have delivered economic, social and environmental value to the community that goes beyond the mere benefits derived from the provision of energy services." [25] (recital 30).

\section{Conclusions}

Citizen energy actors combine their energy business activities with a broader common good orientation in terms of local development, inclusive democracy, citizens' engagement and social innovation. All of these contributions are increasingly needed to counteract the observable loss in acceptance and the growing strength of populism not only with regard to energy issues.

However, attributing these contributions in legislation to a rather narrowly defined group of actors such as in the German definition of citizens' energy companies does not seem to be adequate. It excludes a couple of well-known other decentralized initiatives as the municipality-based $100 \%$ Energy Regions or certain municipal utilities and other actors which include common good provisions into their energy business activities (see [5]). Moreover, it seems questionable whether the provision of those common goods that help raise acceptance can be realized via a definition of privileges for a 
defined category of actors. It will always be difficult—as evidenced by the German auctions- - to find selective criteria to define the eligible actors that are not vulnerable for "abuse".

If acceptance is perceived as a result of the provision of those common goods as regional development, participation, the experience of self-efficacy as well as social inclusion of vulnerable people, then it seems to be more appropriate to change the bid evaluation criteria, i.e., the criteria defining how bids are awarded.

Currently, the bid selection in the German scheme works as a price-only selection process, comparable to the majority of auction schemes in the EU.

However, there are examples of multi-criteria approaches to select the winning bids in order to pursue multiple policy goals (e.g., [27]). In France for example, the bid evaluation in the PV auctions is based on the offered price (two thirds) and the environmental impact in the form of the panels' carbon footprint (one third). The German solar branch has repeatedly referred to the French approach as more suitable than the German price-only approach, because it better protects domestic producers of solar panels as they perform better with the environmental criteria then their competitors for non-European countries.

Another example is the South-African "Renewable Energy Independent Power Project Procurement Program" that strongly relies on non-price factors in bid evaluation. The bid price counts for 70 percent, whereas the remaining 30 percent are given to a "composite score covering job creation, local content, ownership, management control, preferential procurement, enterprise development and socioeconomic development" [28].

Including these secondary objectives into the bid evaluation criteria means-of course-com-promising on the economic efficiency of auction schemes. It clearly increases costs for bidders and the regulator in evaluating these bids. However, in most of the countries where these secondary objectives have been applied in bid evaluation, they helped to promote social acceptability of RE expansion policy and local economic development [27] (p. 39).

Whether to exempt those projects which are assumed to provide such added value from competitive auctions altogether or whether to include these objectives into bid evaluation criteria, depends on a sophisticated cost-benefit analysis, which goes beyond the mere consideration of static cost efficiency. If the proclaimed "secondary" objectives of the German auction scheme are more than just lip service, then policy makers have to devote more attention to them.

Having in mind the increasing share of citizens who feel disconnected to their political elites in Germany as well as in other countries of the European Union-and energy transition mirrors that development-it becomes clear that addressing public welfare and social inclusion have to be key objectives of further energy transition effort.

The added value provided so far by community energy actors-including municipalities, cooperatives and other decentralized community-based actors-in the form of democratization of energy business, opening opportunities to experience social self-efficacy, local development and social inclusion should be honored by democratic policy makers facing growing voter's mistrust and populist political competitors.

It will not suffice to think only in terms of providing a level playing field in energy related economic activities in an imperfect market for purely competition concerns. Instead, there is a need to create a level playing field for common-good-oriented visions and paradigms on societal and energy transition trajectories.

Funding: This article is largely based on research conducted as part of the project "Impact of political framework conditions on citizens' engagement" at the Technical University Munich (TUM). The TUM-project is part of the working package "Change in Multi-Level Governance-Systems" of the KOPERNIKUS-Project "ENavi" funded by the German Ministry for Education and Research (BMBF). Furthermore, the author acknowledges support by the German Research Foundation and the Open Access Publication Fund of the Freie Universität Berlin.

Acknowledgments: The author would like to thank the three anonymous reviewers for their comments.

Conflicts of Interest: The author declares no conflict of interest. 


\section{References}

1. European Commission. Clean Energy for All Europeans. Available online: https://ec.europa.eu/energy/ en/topics/energy-strategy-and-energy-union/clean-energy-all-europeans (accessed on 29 August 2018).

2. European Parliament. Promotion of the Use of Energy from Renewable Sources; Amendments Adopted by the European Parliament on 17 January 2018 on the Proposal for a Directive of the European Parliament and of the Council on the Promotion of the Use of Energy from Renewable Sources (Recast) (COM(2016)0767-C8-0500/2016-2016/0382(COD); P8_TA-PROV(2018)0009; European Parliament: Brussels, Belgium, 2018.

3. European Commission. Communication from the Commission: Guidelines on State Aid for Environmental Protection and Energy 2014-2020 (2014/C 200/01); European Commission: Brussels, Belgium, 2018.

4. Tews, K. Europeanization of Energy and Climate Policy: The Struggle Between Competing Ideas of Coordinating Energy Transitions. J. Environ. Dev. 2015, 24, 267-291. [CrossRef]

5. Beermann, J.; Tews, K. Decentralised laboratories in the German energy transition. Why local renewable energy initiatives must reinvent themselves. J. Clean. Prod. 2017, 169, 125-134. [CrossRef]

6. Holstenkamp, L. Definition und Marktanalyse von Bürgerenergie in Deutschland; Research and Leuphana Universität Lüneburg: Lüneburg, Germany, 2013.

7. Holstenkamp, L.; Kahla, F.; Degenhart, H. Finanzwirtschaftliche Annäherungen an das Phänomen Bürgerbeteiligung. In Handbuch Energiewende und Partizipation; Holstenkamp, L., Radtke, J., Eds.; Springer: Wiesbaden, Germany, 2018; pp. 281-302.

8. Ecofys. Design Features of Support Schemes for Renewable Electricity; A Report Compiled within the European Project “Cooperation between EU MS under the Renewable Energy Directive and Interaction with Support Schemes"; European Commission, DG ENER: Utrecht, The Netherlands, 2014.

9. Grashof, K.; Kochems, J.; Klann, U. Charakterisierung und Chancen kleiner Akteure bei der Ausschreibung für Windenergie an Land; Fachagentur Wind an Land e.V.: Berlin, Germany, 2015.

10. Bundesnetzagentur. Pressemitteilung. Ergebnisse der Gemeinsamen Ausschreibung von Wind- und Solaranlagen; Bundesnetzagentur für Elektrizität, Gas, Telekommunikation, Post und Eisenbahnen: Bonn, Germany, 2018.

11. BMWI. Informal English Version of the EEG 2017. Available online: https://www.bmwi.de/Redaktion/DE/ Downloads/E/eeg-2017-gesetz-en.pdf?_blob=publicationFile\&v=8 (accessed on 20 April 2018).

12. Holstenkamp, L. Einleitende Anmerkungen zum Ländervergleich: Definition von Bürgerenergie, Länderauswahl und Überblick über Fördermechanismen. In Handbuch Energiewende und Partizipation; Holstenkamp, L., Radtke, J., Eds.; Springer: Wiesbaden, Germany, 2018; pp. 897-920.

13. Bundesnetzagentur. Beendete Ausschreibungen. Available online: https://www.bundesnetzagentur. de/SharedDocs/Downloads/DE/Sachgebiete/Energie/Unternehmen_Institutionen/Ausschreibungen/ Hintergrundpapiere/Statistik_Onshore.xlsx;jsessionid=CBEB8E4AF8685DF558604B2020D25E1F?_blob= publicationFile\&v=1 (accessed on 14 June 2018).

14. Bundesnetzagentur. Pressemitteilun. Ergebnisse der Ersten Ausschreibung für Wind an Land. 19 May 2017. Available online: https://www.bundesnetzagentur.de/SharedDocs/Pressemitteilungen/ DE/2017/19052017_Onshore.html (accessed on 14 June 2018).

15. Bundesnetzagentur. Pressemitteilung. Ergebnisse der Zweiten Ausschreibung für Wind an Land. Available online: https:/ / www.bundesnetzagentur.de/SharedDocs/Pressemitteilungen/DE/2017/ 15082017_WindAnLand.html (accessed on 14 June 2018).

16. Erneuerbare Energien. Interview mit UKA-Chef. Ich Bin für Einen Funktionierenden Markt. 2017. Available online: https:/ / www.erneuerbareenergien.de/ich-bin-fuer-einen-funktionierenden-markt/150/ 434/105190/6 (accessed on 23 April 2018).

17. Online Handelsregister (Trade Register). Available online: www.online-handelsregister.de (accessed on 23 April 2018).

18. Herrmann, N. Heilt Die EEG-Notoperation den Fehlstart des Ausschreibungssystems? EMW, Inc.: Herndon, VA, USA, 2017; Volume 4, pp. 1-5.

19. Die Welt. Die Schmutzigen Tricks mit der Bürgerenergie. 2017. Available online: https://www. welt.de/wirtschaft/article165807760/Die-schmutzige-Trickserei-mit-der-Buergerenergie.htm (accessed on 20 August 2018). 
20. Deutscher Bundestag. Antrag der Fraktion Bündnis 90/Die Grünen. Ausbau der Windenergie Sichern, Klimaschutz Voranbringen und Standort für Zukunftstechnologie Erhalten; Drucksache 19/450. 17.01.2018; Deutscher Bundestag: Bonn, Germany, 2018.

21. Berkhout, V.; Cernusko, R.; Grashof, K. Ein Systemwechsel ohne Vorteile; Energie und Management: Herrsching, Germany, 2018; Available online: https:/ /www.energie-und-management.de/nachrichten/alle/detail/einsystemwechsel-ohne-vorteile-123389 (accessed on 14 June 2018).

22. Deutscher Bundestag. Gesetzentwurf der Fraktionen der CDU/CSU und SPD; Entwurf eines Gesetzes zur Einführung von Ausschreibungen für Strom aus Erneuerbaren Energien und zu Weiteren Änderungen des Rechts der Erneuerbaren Energien; Drucksache 18/8860, 21.06.2016; Deutscher Bundestag: Bonn, Germany, 2016.

23. Bundesverband Wind Energie. Ausschreibungen-EU-Wettbewerbskommissarin zum Thema de-Minimis. 2016. Available online: https:/ / www.wind-energie.de/presse/meldungen/detail/ausschreibungen-euwettbewerbskommissarin-zum-thema-de-minimis/ (accessed on 15 January 2018).

24. Hauser, E.; Hildebrand, J.; Dröschel, B.; Klann, U.; Heib, S.; Grashof, K. Nutzeneffekte von Bürgerenergie. Eine wissenschaftliche Qualifizierung und Quantifizierung der Nutzeneffekte der Bürgerenergie und ihrer Möglichen Bedeutung für die Energiewende; Greenpeace Energy eG and Bündnis Bürgerenergie e.V.: Saarbrücken, Germany, 2015.

25. European Commission. Proposal for a Directive of the European Parliament and of the Council on Common Rules for the Internal Market in Electricity; 2016/0380 (COD), 23.2.2017 COM(2016) 864 final/2; European Commission: Brussels, Belgium, 2017.

26. Council of the European Union. Proposal for a Directive of the European Parliament and of the Council on Common Rules for the Internal Market in Electricity; Interinstitutional File: 2016/0380 (COD), 20 December 2017, 15886/17; European Union: Brussels, Belgium, 2017.

27. Wigand, F.; Förster, S.; Amazo, A.; Tiedemann, S. Auctions for Renewable Support: Lessons Learnt from International Experiences. Report D4.2, June 2016. Available online: https:/ /www.ecofys.com/files / files / aures-wp4-synthesis-report-final.pdf (accessed on 20 May 2018).

28. Eberhard, A.; Kolker, J.; Leigland, J. South Africa's Renewable Energy IPP Procurement Program: Success Factors and Lessons. 2014. Available online: http:/ / www.gsb.uct.ac.za/files/ppiafreport.pdf (accessed on 20 May 2018).

(C) 2018 by the author. Licensee MDPI, Basel, Switzerland. This article is an open access article distributed under the terms and conditions of the Creative Commons Attribution (CC BY) license (http://creativecommons.org/licenses/by/4.0/). 